\title{
Cattle Grazing Impacts on Small Cleared Areas in Dense American Elm Woodlands
}

JAMES F. GEORGE AND JEFF POWELL

\section{Abstract}

Removal of overstory canopy of American elm (Ulmus americana) greatly increased the utilization of understory herbaceous vegetation by cattle. Cattle browsing killed all the elm sprouts.

American elm (Ulmus americana) is an important component of stream-course and flood plain woodlands of central Oklahoma and is invading contiguous uplands (Rice and Penfound 1959). This increase in overstory cover not only decreases production of forage species, but also decreases palatability of those plants present (Welton and Morris 1928; Halls and Epps 1969).

In a study in northern Oklahoma, Dwyer (1961) found that cattle browsed American elm, often maintaining individual trees in a shrub-like state. Dalrymple et al. (1965) reported that Winged elm ( $U$. alata), a similar species, was heavily browsed by cattle in Oklahoma.

The objectives of this study were to determine the effects of top removal and fertilization of an American elm woodland on utilization of understory herbaceous vegetation and woody sprouts by cattle.

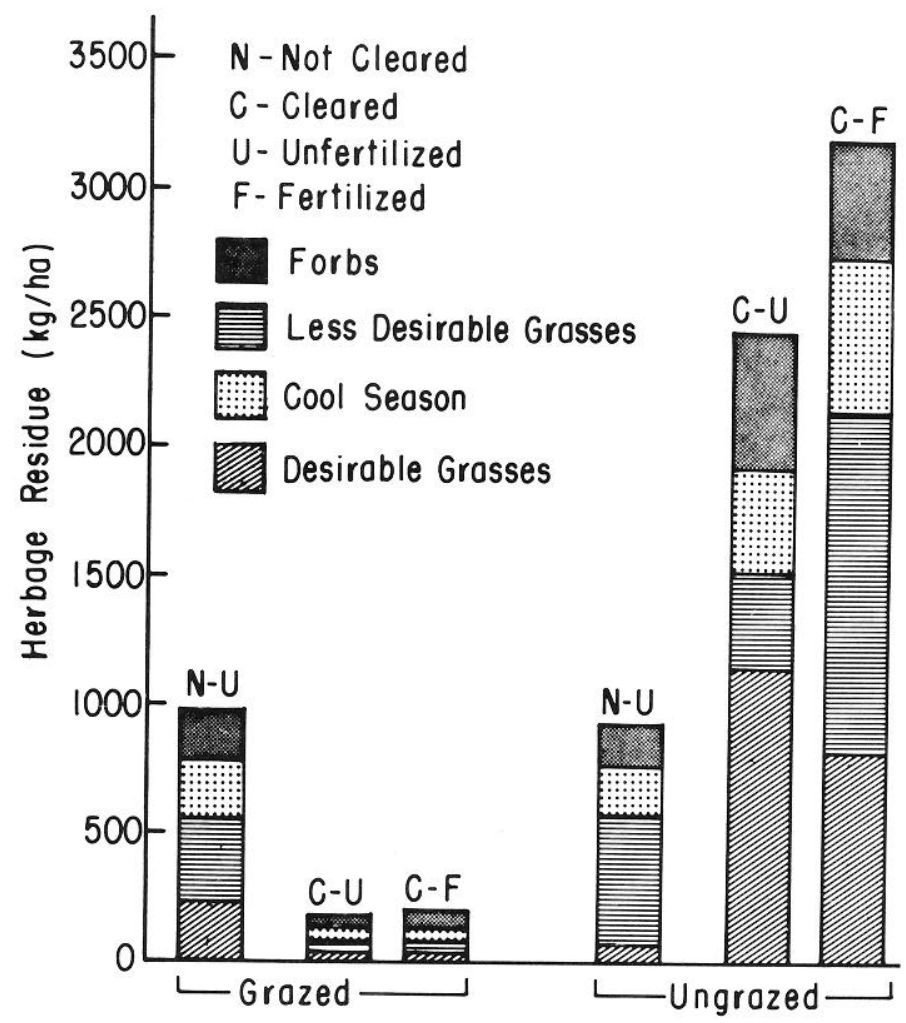

Fig. 1. Herbage residue ( $\mathrm{kg} / \mathrm{ha}$ oven-dry) remaining at end of 1973 growing season.

Authors are research assistant and associate professor, Department of Agronomy, Ohlahoma State University. Stillwater. James George is, at present, range scientist, El Paso Natural Gas Company. El Paso, Texas.

The research is a contribution of the Oklahoma Agricultural Experiment Station as Journal Article Number 3424.

Manuscript received February 21, 1978.

\section{Study Area}

The study area is located in Payne County, Oklahoma, about $18 \mathrm{~km}$ west of Stillwater. The study site is a transition zone between an upland tallgrass prairie and a flood plain woodland. The site was cultivated prior to the mid-1930's and has since been invaded by American elm.

The annual precipitation averages $820 \pm 250 \mathrm{~mm}$. The average precipitation distribution during the 210-day growing season is $21 \%$ during April and May, 28\% during the June-August period, and $17 \%$ during September and October.

The overstory vegetation consisted of a dense stand of uniformsized trees, $97 \%$ of which were American elm. The stand contained about 2,500 trees per hectare, with an average basal diameter of $10.0 \pm 2.2 \mathrm{~cm}$. The herbaceous species were grouped into four species classes. Dominant desirable grasses (preferred by cattle) included Schizachyrium scoparium, Tridens flavus, and Panicum scribnerianum. Less desirable grasses were predominately Andropogon virginicus, Bothriochloa saccharoides, Leptoloma cognatum, Setaria spp. and Sporobolus asper. Cool-season grasses and grass-like plants included Bromus japonicus, Carex spp., and Elymus virginicus. Dominant forbs were Ambrosia psilostachya, Veronia baldwinii, and Desmodium sessilifolium.

\section{Methods}

The study was conducted in a grazed paddock of 9.7 ha and an adjacent, ungrazed area. The grazed area was moderately stocked with

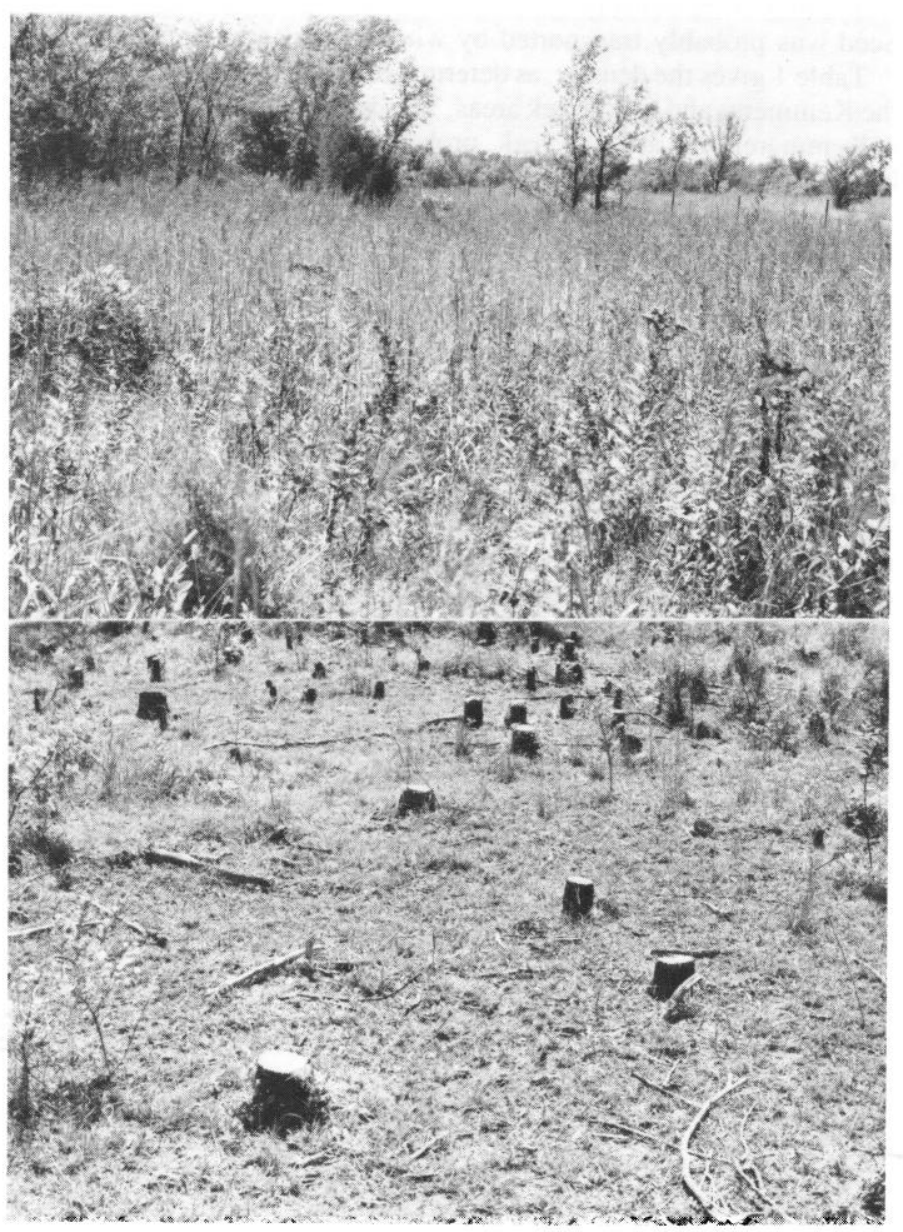

Fig. 2. View of $(A)$ ungrazed and $(B)$ grazed plots. 
